\title{
Disasters Impacting Negatively on Education: A Call for Renewed Intervention Strategies in Kenya
}

\author{
Sikulu S. David \\ Masinde Muliro University of Science and Technology, Kenya \\ Ndiku M. Judah \\ Masinde Muliro University of Science and Technology, Kenya \\ Wanjala N. Lilian \\ Masinde Muliro University of Science and Technology, Kenya
}

\begin{abstract}
Natural and man-made disasters have wreaked havoc in society since time immemorial. Kenya has not been spared by the wide spread of such disasters. As demonstrated, disasters keep on reoccurring with higher intensity than before with an attitude and mode of operation of responding after the disasters have struck. This happens in a back drop of a more conscious society which is aware of its rights. Such a society may demand its rights for protection as a basic right enshrined in the Kenya Constitution 2010 and other international protocols. Out of this thinking, it may be necessary to rethink of novel ways to mitigate disasters especially among the most vulnerable, school going children. This paper discusses the different disasters and their impact in Kenya. Emphasis has been put on the impact of disasters on education. The paper suggests new ways to mitigate disasters affecting school children in line with the new thinking articulated in the literature in Education in Emergencies. A call for more conscious societies to take action to intervene on disasters affecting children is recommended.
\end{abstract}

Key terms: Disasters, Disaster Management, Education in Emergencies

\section{INTRODUCTION}

Education is critical for all children, but it is especially urgent for the tens of millions of children affected by emergencies, be they man made or natural disasters. Yet, for millions of children affected by disaster and crisis, the right to education remains an unfulfilled promise. All individuals have a right to education, and those affected by emergencies are no exception, even during conflict and natural disasters (INEE, 2010). The UN GA resolution on 'the right to education in emergency situations' emphasizes the obligation to secure education for all children regardless of context (UNICEF 2008).

The concept of Education in Emergency sprung up in early 1990s and was popularized at the turn of the century as a pillar of humanitarian aid in the face of multiple international human crises like ethnic-oriented conflicts, drought, earthquakes, volcanoes, Tsunamis, floods, among others. Education in Emergencies (EiE) is the provision of quality education opportunities that meet the physical protection, psychosocial development and cognitive needs of learners affected by emergencies which can be both life sustaining and lifesaving. Quality education and alternative learning opportunities, contributes directly to social, economic and political stabilities of societies. Education is an opportunity to build back, after a disaster, better for a peaceful, prosperous society. 


\section{DISASTER SCENARIOS}

Not all disasters happen at the same speed. Consider the following two examples:

1. Typhoon Haiyan / Yolanda made landfall in the Philippines on the 8th of November. It had been identified as one of the most powerful Typhoons ever recorded only hours before. In a few hours it had killed 6,000 people and injured nearly 30,000. The typhoon displaced 4 million. By the 9 th of November the storm had moved into Vietnamese and Chinese territory.

2. In July 2011 a severe drought hit the Horn of Africa. It lasted almost an entire year. By September 2012 nearly a million people had fled Somalia to camps in Kenya and Ethiopia. Early warning systems first forecast the looming disaster 11 months before it hit. The massive displacement was created partly by the fact the region had been made more vulnerable by previous droughts.

Rapid-onset disaster unfold almost instantly, slow-onset disasters can be predicted much further in advance and unfold over months or even years. Rapid-onset disasters tend to create their destruction through the immediate physical impacts. Slow-onset disasters also create crises through the economic and social impacts of the disaster.

\begin{tabular}{ll}
\hline Slow-onset & Rapid-onset \\
\hline Drought & Cyclones, Typhoons, Hurricanes \\
Desertification & Storm surge \\
Sea level rise & Flash flooding \\
Erosion & Earth Quakes \\
Water salination & Volcanic eruptions \\
\hline \multicolumn{2}{c}{ UK Climate Change \& Migration Coalition }
\end{tabular}

\section{IMPACTS OF DISASTERS ON EDUCATION}

It is clear as afore-mentioned that some disasters occur at a slow pace but the impact is nevertheless as tragic as rapid onset disasters. Some of the emergency situations in Education affect the victims and show their tragedy over a period of time. Whether the situations occur as rapid or slow, education is interrupted and a lot of school time lost in areas affected by disasters. These disasters put many children at risk, exposing them to dangerous and rapidly changing situations. The quality of Education is affected by disasters and emergencies have for long impacted the education sector. Disruption of school calendar due to disaster impacts, including common use of school buildings as temporary shelters and disruption of school calendar due to teachers returning to community of origin following the disaster ( $\mathrm{Ndiku}$, 2011).

Disasters make schools inaccessible due to disruptions in transportation systems, destroyed roads, bridges, damage school structures, learning materials and equipment; cause psychosocial trauma leading to attention-deficit problems and lack of focus in the classroom by learners; children miss schools, learn in sub-standard environments and increases the school dropouts. Community services and support mechanisms are disrupted as a result of these disasters, leaving children vulnerable to risks of sexual exploitation, child labour and rape (Ndiku, 2011).

Education provides a stable environment for children when these disasters occur, protecting them from risks and physical harm and restoring a sense of normalcy. Providing education in emergencies (EiE) also mitigates the negative impact of emergencies on development; protracted crises reverse progress towards achieving education development goals such as Education for All and Vision 2030. Emergencies also deny children the right to free and compulsory basic education as enshrined in the Kenya Constitution 2010. There still remain a number of vulnerable children who face challenges in accessing quality education due to 
natural or man-made disasters especially in marginalized districts and nomadic areas of Arid and Semi-Arid Lands. In Kenya for instance, on average, drought events affect an estimated 250,000 school-age children and 8000 teachers annually due to varying severity levels. Education in Emergencies provision fulfils the basic right of children to education and is lifesaving, life-sustaining and life-enhancing in a humanitarian context.

Kenya, like many other countries has experienced an increase in the frequency of disasters over the past two decades. Driven by climatic change occurrences, naturally occurring hazards such as droughts, floods, landslides and epidemic outbreaks, and coupled with man-made disasters such as fires, ethnic conflict, terrorism, road traffic accidents and technological accidents which disrupt people's livelihoods, destroy infrastructure, divert planned use of resources and interrupt education system and economic activities. These disasters are a key impediment to sustainable development in Kenya as the number of people affected and the amount of property damaged continues to increase, thus leading to rising economic losses (DFID, 2004a). Approximately 75\% of the world's population lives in areas that have been affected by disasters at least once between 1990 and 2000 and average of 184 people die every day as a result of disasters (IFRC, 2003).

Summarized Table of Natural Disasters in Kenya from 1900 to 2015

\begin{tabular}{|c|c|c|c|c|c|}
\hline DISASTER & AVER. PER EVENT & \# of Events & Killed & Total Affected & Damage (000 US\$) \\
\hline \multirow[t]{2}{*}{ Drought } & Drought & 14 & 196 & 48800000 & 1500 \\
\hline & ave. per event & & 14 & 3485714.3 & 107.1 \\
\hline \multirow[t]{4}{*}{ Earthquake } & Ground movement & 1 & - & 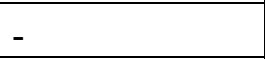 & - \\
\hline & ave. per event & & - & - & - \\
\hline & Tsunami & 1 & 1 & - & 100000 \\
\hline & ave. per event & & 1 & - & 100000 \\
\hline \multirow[t]{8}{*}{ Epidemic } & Unspecified & 4 & 1273 & 22538 & - \\
\hline & ave. per event & & 318.3 & 5634.5 & - \\
\hline & Bacterial disease & 17 & 1402 & 48528 & - \\
\hline & ave. per event & & 82.5 & 2854.6 & - \\
\hline & Parasitic disease & 5 & 1595 & 6807533 & - \\
\hline & ave. per event & & 319 & 1361506.6 & - \\
\hline & Viral disease & 5 & 514 & 3396 & - \\
\hline & ave. per event & & 102.8 & 679.2 & - \\
\hline \multirow[t]{6}{*}{ Flood } & Unspecified & 7 & 228 & 961200 & 21850 \\
\hline & ave. per event & & 32.6 & 137314.3 & 3121.4 \\
\hline & Flash flood & 6 & 100 & 48000 & 500 \\
\hline & ave. per event & & 16.7 & 8000 & 83.3 \\
\hline & Riverine flood & 33 & 996 & 1962423 & 136038 \\
\hline & ave. per event & & 30.2 & 59467.4 & 4122.4 \\
\hline \multirow[t]{2}{*}{ Landslide } & Landslide & 4 & 56 & 26 & - \\
\hline & ave. per event & & 14 & 6.5 & - \\
\hline \multirow[t]{2}{*}{ Storm } & Convective storm & 1 & 50 & - & - \\
\hline & ave. per event & & 50 & - & - \\
\hline Total & & & & & \\
\hline
\end{tabular}

Source: "EM-DAT: The OFDA/CRED International Disaster Database www.em-dat.net - Université Catholique de Louvain - Brussels - Belgium" 
In Africa, between 2000 - 2001, about 35 million people, which is equivalent to $13 \%$ of the total population in Africa, were affected by disasters. In terms of economic losses, disasters significantly derail development in affected countries. In addition to such large, discrete and high impact, hazards erode the development capacity and livelihoods of the majority of the poor and weaken their coping and survival capacities (UNDP, 2004).

In the recent past in Kenya, these hazards have increased in number, frequency and complexity. The level of destruction has become more severe with varying magnitudes, resulting in more deaths of people, animals, destruction of infrastructure, resulting in loss of livelihoods.

The frequency of these disasters is reported to have increased in the last decade. Weather triggered hazards, including drought, flood, windstorms, landslides, wildfires, conflicts over resources and politically instigated violence occur most frequently in space and time. They account for most of socio-economic effects of disasters, including the number of people affected.

\section{PAST EMERGENCY PROFILES}

Kenya has experienced both human induced and natural phenomenon with significant increase in natural disasters over the last two decades. The number of weather-related disasters continues to rise. The greatest number of immediate deaths in these disasters is attributed to droughts/famines and floods. Floods affect more people than any other disaster hazard, though medium and longer-term drought and famine impacts are thought to be significantly underreported. Road accidents lead the list of human induced disasters, followed by conflict/insecurity and fires. 2014 long rains assessment established that about 1.5 million people are facing acute food insecurity conditions, after two successive poor or failed rain seasons coupled with adverse effects of high food prices and conflict incidences. These populations largely occur in the northwestern and northeastern pastoral livelihood zones of Kenya (KFSSG, AUGUST 2014).

\section{DROUGHTS}

Kenya is a drought, famine and hunger prone country, primarily because of its peculiar ecoclimatic conditions. Although dissected by the equator in its southern half, Kenya contains only a few pockets of high and regular rainfall. Arid and semi-arid lands cover $80 \%$ of the territory. In these areas, where annual rainfall varies from 200 to $500 \mathrm{~mm}$, periodical droughts are part of the climate system. Drought is a recurrent phenomenon that affects large areas and numbers of people in the country. On average, drought events affect an estimated 250,000 school going children and 8,000 teachers annually with varying severity levels with an estimated 1.5 million people were food-insecure in 2014 (KFSSG AUGUST, 2014). The cumulative effects of these droughts include the depletion of assets, decreasing ability to cope with future droughts, deprivation of rural communities and declining capacity of government to respond. The effects of drought have become more pronounced in recent decades: In the 1990s, there were three major droughts.

For example, the effects of the 1991/92 drought in the arid districts led to livestock losses of up to $70 \%$ and unprecedented high rates of child malnutrition of up to $50 \%$. During this drought 1.5 million people in seventeen arid and semi-arid districts of four provinces received relief food assistance. Rains failed again at the end of 1995 and in 1996, leading to another drought situation, which affected an estimated 1.41 million people. The worst drought emergency in recent years affected the Central, Eastern, Rift Valley, Coast and North Eastern 
Provinces, with 4.4 million people requiring food assistance in the year 2000 ( Kenya DRR Strategy 2006-16).

The Economic Review of Agriculture indicates that 51\% of Kenyan population lacks access to adequate food. Food security, the review says, is closely linked to poverty which is currently estimated at $46 \%$ nationally. The effects of climate change are increasingly felt in the region, and it is particularly the children who bear the brunt. Valuable school going time is often replaced by house hold chores during drought events.

Many households are increasingly becoming vulnerable to food insecurity and are likely to withdraw children from school so as to engage in income generating activities to supplement household food access. There is an increase in mobility of pupils that are migrating with their families in search of pasture and browse for livestock (KFSSG, AUGUST 2014).

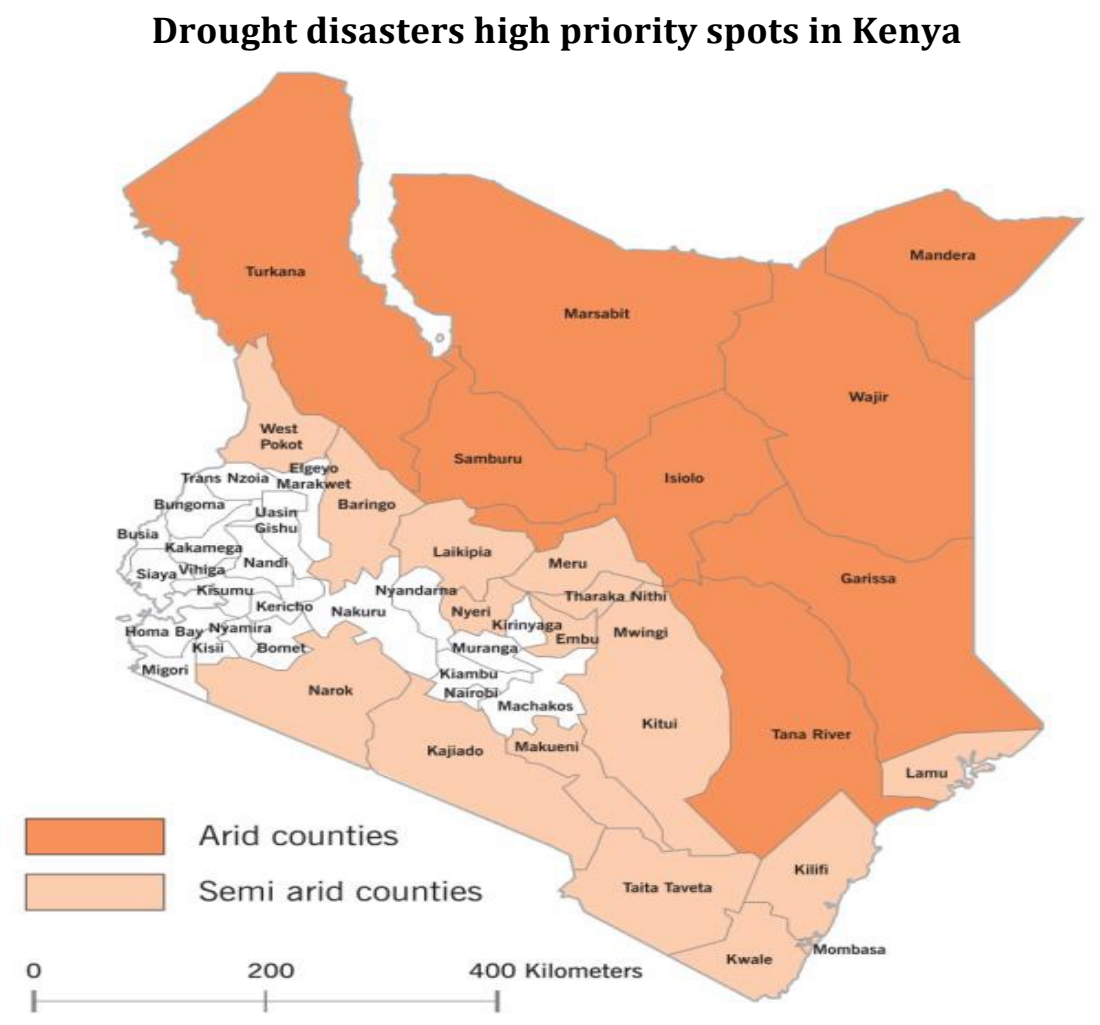

\section{FLOODS}

Both major and flash floods events affect an estimated 200 school facilities, 100,000 school children and 500 teachers in worst case scenario with reported flooding disasters experienced in Western, Nyanza, Eastern, Rift Valley and Coast provinces of Kenya (MOEST 2014). Riverine flooding occurs in Siaya [R. Nzoia]; Tana River [R. Tana]; Kisumu [R. Nyando]; Homa Bay [R. Awach]

Every year, despite the beneficial environmental impacts they create, floods impose substantial economic, social and environmental costs. Even though one is somehow the converse of the other, flooding and drought combined are the most damaging natural hazards in terms of economic costs to the education sector in Kenya. Floods disrupt economic activities, they cause stress, anxiety, interfere with safety of lives to those affected by floods, lead to outbreak and spread and increased morbidity wit, lead to Loss and/or damage to property including school instructional materials and infrastructure. 
Floods have often led to disasters in Kenya. Areas of Kano Plains in Nyanza Province, Budalang'i in Western Province and the lower parts of the Tana River are susceptible to floods, as do in most informal settlements with poor drainage systems such Nyalenda in Kisumu; Mathare, Mukuru, and Kibera slums in Nairobi. Arid and semi-arid areas of the country also experience flash floods especially in Isiolo, Moyale, Garissa, and Marsabit districts.

However, heavy rains have caused flooding in localized areas of the pastoral Districts of Turkana, West Pokot, Baringo, Isiolo, Kajiado and Narok; parts of the grain basket including Kericho and Nakuru Districts; localized areas of the southeastern and coastal marginal agricultural areas of Kitui, Makueni, Malindi, Tana River and Taita Taveta; and the Lake region Districts of Nyando, Kisumu, Siaya, and Rachuonyo, from late October 2009 to early January 2010 (EPRP/MOE 2010). In many of these regions livelihoods remain vulnerable to the impacts of shocks and hazards, in spite of emergency interventions. Asset building interventions are required to restore productive capacities, ahead of the long rains season.

Renewed flooding in early March 2010, reported in Isiolo, Samburu, Moyale, Marsabit, Mandera and Turkana Districts, displaced about 8,000 persons, while 11 lives were reportedly lost. In addition, significant losses including loss of crops, livestock and homes were incurred (NDMA AND KFSSG 2014). In such circumstances, some of the effects on the learners include; inaccessibility of schools, schools being used as rescue centres for the entire community, destruction of school infrastructure, facilities and learning materials, outbreak of epidemics and malnutrition, psycho-social trauma, school dropouts and congestion in schools in unaffected schools all which compromises the realization of quality, access and equity in education.

\section{CONFLICTS}

Ethnic conflicts are caused by several factors, for example, scramble for natural resources such as pasture, minerals, land, water and other resources; border disputes, cultural practices such as cattle rustling, negative ethnicity and advancement of political interests (Ndiku, 2011). Conflicts resulting from terrorism, ethnic and economic tensions, banditry and cattle rustling disrupt the lives of those displaced and the lives of host communities. In this way, the net effect on learning is that learning is disrupted following the insecurity, destruction of learning infrastructure, facilities and materials as well as loss of livelihoods, lives and trauma effect on the part of the learners. Schools are therefore used as temporary shelter for the displaced persons at the expense of learning (ibid).

Terrorist activities such as those experienced in Mombasa, Nairobi, Garissa, Mandera, Lamu counties and Moyale in Marsabit county also negatively on education by creating insecurity amongst education stakeholders/players. Political instability in our neighboring countries has resulted in cross border influx of refugees in Kenya. This has led to the overstretching of resources meant for education (source).

The continuing influx of young refugees into the country from neighbouring countries especially Somalia and South Sudan has often required that MOEST and Education Cluster members support programmes that ensure their access to education.

Following the post-election violence after the 2007 general election, mass displacements and forcible evictions of people not indigenous to particular regions resulted. About 350,000 Kenyans were displaced with 1,162 reported deaths (KHRC 2008). More than 1000 teachers were displaced and lost property with an estimated 160,000 learners displaced. There was disruption of normal life and learning/teaching adversely affected. 
Violent conflicts involving pastoralists have become widespread and increasingly severe in the North Rift and North Eastern regions of Kenya. Approximately 2 million people are affected by conflict either directly or indirectly in Kenya a majority being pastoralists. Conflicts involving pastoralists associated with resource competition, cattle rustling and wide availability of small arms are widespread and of increasing concern. Conflicts involving pastoralists associated with resource competition, cattle rustling and wide availability of small arms are widespread and of increasing concern. Conflict leads to destruction of social amenities already put in place. For example, the education system is affected when teachers are forced to withdraw from conflict stricken areas and the communities re-locate their settlements for fear of being invaded. Education for children and the youth is affected and interrupted both in the short and long run. Conflict also acts as a disincentive to investment by the communities and development agencies, both in the long-term and short-term. At the local level, a lot of effort and funds go to contain conflicts and to mitigate against conflict-related effects rather than being channeled to development work.

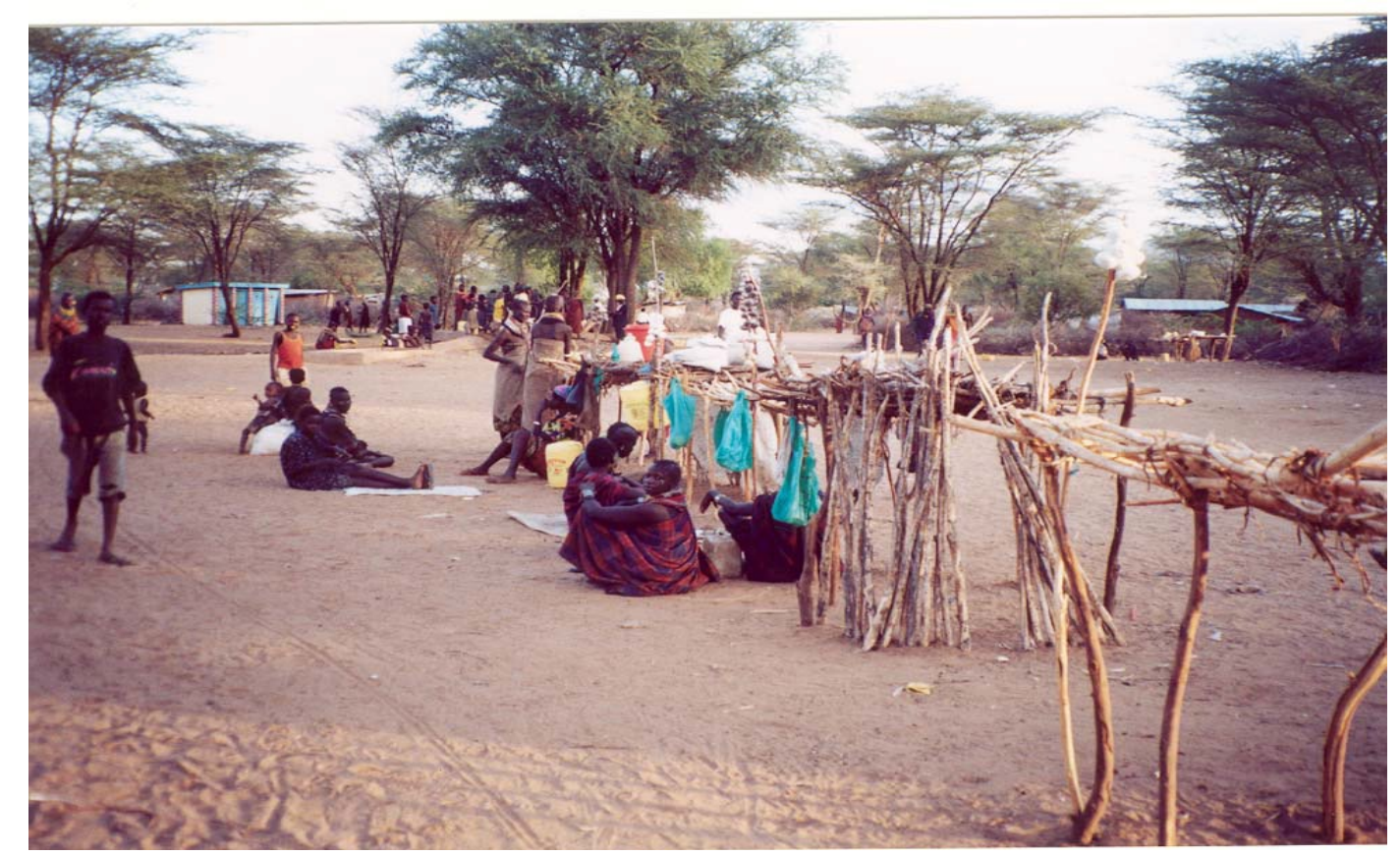

Internally displaced women selling firewood at Lokichogio, Turkana (Conflict in Northern Kenya, ITDG-EA 2003)

\section{FIRE}

Fires in schools in Kenya are caused by electrical faults, dissatisfied students who communicate through burning their buildings, suspected arsonists both from within and outside the schools and accidents in laboratories and Kitchens. Kenya has experienced incidents of fire on a wide scale in the last few years in homes and boarding secondary schools. The Kyanguli, Bombolulu and Nyeri Boys High Schools' disasters have remained fresh in the minds of Kenyans. Nearly every week there are incidents of destructive fires in Kenyan secondary schools. Most of these are suspected arson cases and the usual suspects are the schools' current students. During the 2013 school year Kenyan media reported at least 34 separate cases of fires as suspected arson in secondary schools, as well as several more thwarted attempts at arson in schools. This is comparable to the 28 separate incidents of suspected arson in secondary schools in 2012 and the 14 cases reported in 2011. 
About 48 cases of fire outbreaks in schools were reported in 2012 resulting in 22 deaths of students and teachers while in 2008 high student unrests were reported in learning institutions, with13 reported cases resulting into deaths of students in that year alone. Reported fire incidents in 2013 and 2014 include one at Kihome secondary school in Othaya where a dormitory caught fire a few hours before KCSE examinations. No student was injured in the $9 \mathrm{pm}$ incident. Homa bay high school had three incidents of fire in which a dormitory was burnt in July and two others in September the same year. In the 3 incidents property worth millions of shillings was destroyed after the more than 240 students who were staying in those dormitories failed to save their belongings from the fire.

Property worth millions of shillings was reduced to ashes in two secondary schools following separate fire incidents. A 9pm fire broke out at Nyayongi mixed secondary gutting down a dormitory that houses 80 students. The next day at 9pm, fire broke out at Nyabisawa Girls high school dormitory that houses 160 students was razed to the ground.

These fire incidents in schools disrupt learning as students are traumatized for having lost their property besides being left without instructional material. More so, when buildings are burned students have to be congested in smaller rooms before others can be put up. In cases where arsonists are found to be students themselves, parents are surcharged resulting into some of them transferring their children to other schools.

Finding on serviceability of fire extinguishers noted that only $43 \%$ of the schools surveyed had actually serviced the fire extinguishers. The rest (57\%) had never renewed nor serviced the gadgets since installation. Again, this is a pointer towards the risky disposition the learning institutions in Kenya are exposed to. There is need to cushion them from the risk of fire outbreaks.

\section{Road Traffic accidents}

\section{OTHER DISASTERS IMPACTING NEGATIVELY ON EDUCATION}

The rate at which road accidents involving school buses and vans in Kenya is happening leading to deaths is quite alarming. Clear examples include those that happened in the year 2013 which include the instance in Nyahururu where police officers impounded three school buses for overloading with one of the buses carrying 26 extra students than its capacity allows while the other two had overloaded by 17 and 12 respectively all headed for Nakuru for an education tour. The other one is the accident in which 4 students of Nambale High school in Busia County were confirmed dead following a deadly road accident that involved their school bus and a lorry along Nakuru-Kabarnet road. There is also the case of students from two private schools; Compuera Academy and Richbrain Academy were injured in two separate accidents that occurred while they were being driven to school on Valley Road and Ngong Road respectively. The accident involving the pupils from Compuera Academy led to injured 9 pupils and some staff while in the one of Richbrain Academy, 7 pupils were injured. More recently, is the accident that occurred in Kisii County involving a school bus for Rioma Secondary School where 13 people, including nine students and four teachers lost their lives.

Such accidents on the roads involving school children directly affect the education of these children. Their continued occurrence gives clear indications that this phenomenon is fast acquiring the proportions of a disaster or an emergency that directly and adversely affects education of the children involved hence the need for MoEST and other educational stakeholders and partners to address it. 


\section{Teenage pregnancies}

Teenage pregnancy has been on the rise in Kenya for many years and the situation is likely to get out of hand if nothing is done. According to studies, nearly 3 in every 10 teenage girls are having babies. The age bracket is normally between 15 to 19 years and in most cases these are normally school going children either in primary or secondary school, who as a result of the unwanted pregnancies are forced to drop out of school. In 2013 for instance, independent investigations in Mt Elgon by The Standard had established that at least 50 girls drop out of school each term in the region. This unfortunate phenomenon is further clearly illustrated by the example of Naivasha primary school which in February 2014, the standard newspaper reported to have had cases of school girl pregnancies reported as follows: one case in 2008, one case in 2009, eight cases in 2010, ten cases in 2011, three in 2012 and eight in 2013. The seeming increase in the frequency of such instances is indeed worrying and if no educational efforts are made to address it, it can escalate to disastrous proportions (MOEST, 1st EPRP draft 2015)

\section{Landslides}

Landslides in Kenya have been on the increase in the recent past. In Kenya landslides and mudslides occur mostly during the rainy season and are accelerated by flooding. Landslides are triggered by rapid saturation of the soil, which in turn reduces cohesion, surface tension and friction. Despite their occurrence having both social and economic impacts mainly loss of life, agricultural land and crops as well as destruction of infrastructure, landslides continue occur almost every year in the various parts of this country. For instance, in 1997, a landslide occurred along the Thika-Murang'a highway at Karugia, sweeping away a one-kilometer section of the highway downslope rendering about $356 \mathrm{~km} 2$ of arable land useless in addition to cutting off road and other communications between Thika and Murang'a towns, which are major administrative and commercial centres with very rich agricultural hinterlands. Another landslide occurred at Gatara village located in Murangia, which swept away an estimated 50,000 tea bushes as well as killing 3 people who were buried while asleep in their house.

In 1998 a landslide occurred along the Embu-Meru highway washing away a 3-kilometer section of the highway including a moving bus carrying about 70 passengers into a deep ravine on the slopes of Mount Kenya as well as killing 36 passengers leaving the critically injured. In the same year, another landslide occurred, along the Thika-Garissa highway at Makutano and sweeping away a bridge, cutting off the eastern part of Kenya from the rest of the country in the same way it did in another landslide that occurred, near Kibwezi market on the main Nairobi-Mombasa highway that destroyed a major bridge. Later instances of landslides include the one that occurred in Kakamega in Kuvasali area in 2007, Elgeyo Marakwet in Kocholwo, Simit, Kapsokom, Kaptarkom and Toroplongon areas of the county in 2012 killing at least 10 people, some parts of Narok such as Olutrot village in 2013.

In all these occurrences, there occur some displacements of people including school going children as well as destruction of schools and learning materials. It is in this way that such disasters require recognition especially from the educational sector mainly because the children affected end up having their opportunity for education compromised.

\section{Drug and Substance Abuse}

Drug and substance abuse is a global problem and is one of the major problems affecting the youth both in school and out of school. Substance abuse has become a major challenge in secondary schools in Kenya. Studies carried out in Kenya indicate that $20 \%$ of adolescents aged between 12 and 22 years smoke cigarettes, 9\% smoke bhang while $23 \%$ drink commercial 
beer and spirits. This is the age in which most youths are in schools and colleges. At the same time, other studies have shown that more than a fifth $(22.7 \%)$ of primary school children take alcohol, a figure that rises to more than three-quarters $(68 \%)$ for university students. This problem impacts negatively on the academic, social, psychological, economical and physiological development among the youth who abuse drugs. The dimensions that this problem is taking clearly indicates that unless education as a sector focuses on it with an aim of mitigating it, sooner or later, it will assume disastrous proportions thereby negatively impacting on the youths' education(MOEST, 1st EPRP draft 2015).

\section{Female Genital Mutilation}

Female genital mutilation (FGM) is the term used to refer to the removal of part, or all, of the female genitalia. It is estimated that 3 million girls are at risk every year only in the African continent. In Kenya the Children's Act in 2001 banned the practice for all girls under the age of 18 , but as newspaper reports show, this has had but a small effect. For example, the Somalis who live predominantly in the North Eastern province practice FGM at a rate of $97.7 \%$, with $75 \%$. There is also Kisii (also known as the Abagussi or Gusii) at $96.1 \%$ and the Maasai at 73.2\%. By contrast, the Luhya and Luo have the lowest rates of less than 1\%. (DHS 2008-09). As has been noted, in Kenya, FGM is performed mostly on girls aged between 12 and 18. Some studies have however, shown that girls are now being cut earlier, between the ages of 7 and 12 . Nonetheless, it is notable that the procedure, although illegal, is often done in secret. Girls are often married almost immediately after the ritual, thus dropping out of school. Therefore the issue is also one of education for young women.

In the Pokot region for example, where over 50 percent of girls between the ages of 10 and 21 years have reportedly been subjected to FGM; local officials indicate that over $80 \%$ of girls either do not join school or drop out prematurely after undergoing FGM, as girls are often married off immediately after the procedure. This severely undermines their attainment of educational goals. With all these negative effects on education, coupled with the fact that the incidences of school strike are on the increase, school strikes are fast becoming a disaster that may soon be overwhelming if the education sector does not address it in good time (MOEST, 1st EPRP draft 2015).

\section{School Strikes}

School strikes Kenyan schools is not a new phenomenon all over the world in institutions of learning. In Kenya, cases of school strikes have been in existence as far back as the beginning of the 20th century when the first case was reported in Maseno School in 1908 (Republic of Kenya, 2001). In Kenya for instance, between 1980 and 1990, the number of schools experiencing student unrest and violence increased tremendously from $22(0.9 \%)$ to 187 (7.2\%) and by 2001, this had increased to 250 secondary schools (Republic of Kenya 2001, p.6) with glaring cases in point here include Nyeri High School 25 March 1991 where students locked up four prefects in their cubicles at night and doused them in petrol killing them instantly, St. Kizito Mixed Secondary Schools on 13, July, 1991 where male students invaded girls' dormitory and raped more than seventy girls leaving at least nineteen dead (Kenya Times, 16 July, 1991 pg. 1 col. 7, pg. 10 col. 2-6), Bombolulu Girls secondary school in May 1997 where 57 students perished in a dormitory as a result of fire started by some students, Kyanguli secondary school on 25 March, 2001 where more than sixty five students perished in fire (Institute for Security Studies, 2008) and Kabuyefwe secondary school in Kitale where more than 400 schoolboys went on rampage burning down the administration block and the store and also shattering windows of other buildings angered by poor Kenya Certificate of 
Secondary Education (KCSE) results over the years and what they termed as their teachers' irregular class attendance, among other grievances (Sunday Nation, October 9, 2005).

Other than the increase in the number of schools experiencing student violence, the other concern has been the change in nature and characteristics of this occurrence. Earlier on, these disturbances were confined to secondary schools, middle level colleges and tertiary institutions but in the year 2000, primary schools joined the fray of student unrest and violence (Republic of Kenya 2001).

While incidents of school strikes in the 1960s and 1970s were relatively peaceful, taking the form of boycott of classes and mass walkouts as witnessed at Kericho High School in 1961 and St Mary's School Yala in 1990 (Sagini Report, 1991), they took a new dimension in the 1980s through the 1990s to the 2000s in which they involved wanton destruction of school property, mass rapes and worst of all, loss of human life. Just after the post election violence in Kenya early in the year 2008, violence again erupted in Kenyan secondary schools where several secondary schools' dormitories and administration blocks were set on fire by students whose indiscipline continue to be a source of concern in many parts of the country leading to the closure of about 300 schools in a span of a month.

\section{Examinations}

Examinations have always been a source of a range of feelings of anxiety and fear amongst students, and more so, in secondary schools. In Kenya, in the year 2001, the Nation Newspaper reported an incident where 69 students were burnt to death in a dormitory and several others injured by two students in a Secondary School in Machakos County following the annulment of final examinations results.

In the year 2007, the Kenya Certificate of Secondary Education (KCSE) examinations were reportedly marred by incidents of cheating. In addition to such malpractices, in the course of processing the results, there occurred what was referred to as a 'computer error' leading to errors in grading which affected 40,000 candidates (Daily Nation 27 July 2008 p.6 col.2-4), a scandal that caused a country-wide wave of strikes in secondary schools. Later in the same year, and in second term, there was an outbreak of protest in secondary schools with the form 4 students refusing to sit for mock exams. This fear has often been manifested in malpractices and exam irregularities such as cheating as illustrated in the table below:

Table showing cases of Examination Irregularities in KCSE between the years 2009-2012

\begin{tabular}{|l|rr|r|r|}
\hline Year & $\begin{array}{l}\text { Number of Districts } \\
\text { Affected }\end{array}$ & $\begin{array}{l}\text { Number of Candidates } \\
\text { Affected }\end{array}$ & $\begin{array}{l}\text { Number of Centres } \\
\text { Affected }\end{array}$ \\
\hline 2009 & - & $171(0.35 \%)$ & $69(1.15 \%)$ \\
\hline 2010 & $54(21.60)$ & $539(0.15 \%)$ & $154(2.39 \%)$ \\
\hline 2011 & $84(31.23)$ & $2,927(0.71 \%)$ & $118(1.69 \%)$ \\
\hline 2012 & $71(26.79 \%)$ & $1,700(0.39 \%)$ & \\
\hline
\end{tabular}

Source: KNEC - KCSE Examination Essential Statistics (March 2013)

From this scenario, one can see that examinations have become such a monster to school children and unless the education sector takes conscious steps to lower the rather high stakes in examinations, then they are going to drive most of the children to disillusionment hence compromising the value of education. 


\section{Technology}

Technology has developed fairly fast and continues to develop even more rapidly. This is evidenced in its various manifestations such as internet which is highly utilized in a range of applications such as mass media, and of late, the social media. School children have gotten hooked onto the internet with all its moral shortcomings as well as the social media. In so doing, children not only waste most of their educational time on social media but also spent more time on content that may not be suitable for their level of personal development thereby adversely affecting their educational achievement. It is in this way that it is felt that if such a scenario continues unchecked, it will soon prove disastrous on the part of educational and moral welfare of the school children.

\section{CONCLUSIONS}

Education is seen as a human right, a key to civilization and enlightenment and as source of wealth and power. It's the cornerstone of the growth and development of any country's social economic and political institutions. Disasters have led many schools to be closed, students dropouts have increased, properties destroyed, infrastructure damaged, these have direct effects to the development of our nations. Disaster risk reduction has not so far received serious attention as a facet of development, despite the increasing seriousness of disaster impacts on our education sector and general development. There is an urgent need therefore for all educational stakeholders to seek strategies to solve the pandemic.

\section{RECOMMENDATIONS}

There is need to develop a coherent disaster/emergency preparedness policy and implement it at national, county and sub-county levels. The policy should generate and encourage proactive leadership and prudent use of local resources in handling disaster related issues at grassroots levels.

There is need to urgently organize a sensitization programme for all directorates in the Ministry and key education stakeholders on issues pertaining to Disaster and Emergency preparedness. This initiative will promote ownership of emergency programmes in both central and county governments.

There should be capacity of all levels of education sponsors, managers and administrators in all the 47 Counties. This initiative should be continuous and it should be able to empower all actors and facilitate rapid response to emergencies in rural areas.

Rapid Response Teams should be established at county-level as well as rapid response teams/ committees in all 47 Counties to handle regional emergency situations.

A County emergency fund should be established to cater for disasters through rapid response teams mentioned in No. 4 above.

The Ministry and County officers alike should coordinate synergized responses to emergency situations through coherent networking with international and national humanitarian organizations like UNOCHA, UNICEF, Save the Children, Red Cross, Fire Brigade Department, among others.

The Kenya Power and Lighting Company should urgently survey the state of electrical wiring in schools and make appropriate recommendations. 
An education policy on disaster/emergency preparedness in learning institutions should be established and be implemented at national, county and sub-county levels.

A clear coordination framework on disaster/emergency management response should be formulated.

Capacity building for BOMs/SMCs, Principals, Head teachers and even students on disaster preparedness and management should be held

A way should be found to encourage the culture of openness, transparency, dialogue (communication), democratization in schools and the community to reduce tensions that trigger vandalism and arson.

Education Cluster coordination: to strengthen humanitarian leadership, partnerships and finance (MoEST leads the cluster in Kenya). Enhanced Cluster coordination or Cluster members' stronger commitment in mitigation

\section{References}

Achoka Judith S. K. and Maiyo Julius. Horrifying disasters in western Kenya; Impact on education and national development Masinde Muliro University of Science and Technology, Kenya.7 May, 2008

Adams W M (1990). Green Development Environment and Sustainability in third world Rutledge, London.

Anderson M (1985). A reconceptualization of the Linkages between disasters and development. Disasters: the international journal of disaster studies and practice. (Havard supplement).

Central Bureau of Statistics (2000). Economic Survey of Kenya, 2000.

Cuny, F. (1983). Disaster and Development. Oxford University press. Oxford

Daily Nation (February 9, 2003). Investors In Institutions of Learning Supplementing the Government inadequate Resources.

Daily Nation (September 5th, 2007). Lightening in western province

DFID (2004a) Partnership for Development DFID’s Country plan in India. Country assistance plan, 2004-2008. DFID,London.

IFRC (2003) World Disasters Report 2003: Focus on Ethics in Aid, IFRC/RC, Geneva.

Lavell A (1999). The impact of disasters on development Gains, Clarity or Controversy. Paper presented at the IDNDR programme forum,Geneva 5-9th July 1999.

Makhanu SK (2005). Regional power Integration in Hydropower, project Report for Phase 1, on Regional Power Integration in Hydropower: workshop and seminar on Nile Basin Capacity Building Network for river Engineering (NBCBN-RE), held in 13-16th June 2004, Cairo Egypt, pp. 26-27.

Mango T (2003).The issue of Floods in Budalangi division, (Report for Budalangi floods stakeholders forum, September 10th-11th,2003), Budalangi-Kenya: pp. 1-12.

McCall MK (1995). Indigenious technical Knowledge in farming systems of Eastern Africa: International Institute for Aerospace survey and earth sciences. The Netherlands (Electronic book from Internet).

Nakileza BR (2007). Occurrence of Landslides and Challenges to Rehabilitation of scare for Improved Human Security on Mt Elgon,Uganda. In Int. J. Disaster Manage. Risk Reduction, Vol. No. 1,2007.

Ndiku, J. M.(2011). Role of Teachers in Conflict Transformation. Unpublished Doctor of Philosophy Dissertation. Masinde Muliro University of Science and Technology

Republic of Kenya (2004) Flood Management strategy for Lake Victoria basin Kenya, Draft report. Kenya Red Cross Disaster Relief and Preparedness Handbook. 
David, S. S., Judah, N. M., \& Lilian, W. N. (2015). Disasters Impacting Negatively on Education: A Call for Renewed Intervention Stategies in Kenya. Advances in Social Sciences Research Journal, 2(8) 85-98.

UNESCO/UNEP (1988) Natural disaster and Environmental Connect: Environmental Education Newsletter, Volume 13, no 4, December 1988.UNESCO,Paris France.

United Nations (2001). Roadmap towards the implementation of the United Nations millennium declaration report of the secretary general.

UNDP (2004). Reducing disaster: A challenge for Development: Global Report. UNDP Geneva. 